\title{
Between Precarity and Paternalism: Farm Workers and Trade Unions in South Africa's Western Cape Province
}

\author{
Christopher Webb, University of Toronto, Canada
}

\begin{abstract}
The labour market in rural areas of South Africa's Western Cape province has undergone considerable changes over the last thirty years. New labour and tenure legislation protecting farm workers combined with trade liberalisation, the abolition of subsidies and in-migration from other areas of South Africa has significantly reshaped labour on commercial farms. There is an increasing divide between permanent farm workers and a growing pool of precariously employed workers who labour seasonally on farms and are frequently employed through labour brokers. These divisions came to a head in 2012 when workers, many of whom work seasonally on farms, launched a strike that was to last for six months. Trade unions have struggled to organise an increasingly fragmented rural labour market and at the same time negotiate the forms of paternalism that continue to exert a strong influence over rural labour relations. Based on interviews with trade union organisers, this article examines how they have responded to the twin challenges of labour broking and paternalism. The farm strikes highlight the need for a form of social movement unionism that goes beyond wage demands and tackles the multiple factors that influence poverty in rural areas.
\end{abstract}

\section{KEYWORDS}

farm workers; labour broking; South Africa; agrarian change; paternalism

Between late 2012 and early 2013 a wave of strikes broke out in agricultural districts across South Africa's Western Cape province. The Western Cape province has the highest number of farm workers in the country and accounts for 23.2 per cent of national agricultural GDP (FARE, 2013: 1). Organised independently of trade unions and within a sector not known for its labour militancy, the strikes called attention to high levels of rural poverty and unemployment. While the result of these strikes was a 52 per cent increase in the minimum wage for farm workers, they were not motivated purely by wage concerns but by a host of factors affecting rural livelihoods. The strikes also occurred shortly after the massacre of thirty-four mineworkers at Marikana and in the midst of an extended strike wave in the country's platinum belt. Common denominators in all these strikes were independent forms of worker organising outside of traditional trade union structures (Sinwell and Mbatha, 2016) and a growing dissatisfaction with trade unions allied with the Congress of South African Trade Unions (COSATU).

Research conducted prior to the strikes highlights some of the causal factors that led to farm workers downing tools. In this article, I draw on fieldwork conducted between May and August 2012 with trade unions organising in the agricultural sector in the Western Cape. These unions have 
organised workers in horticulture, viticulture, livestock production and upstream agricultural processing such as canning and bottling. Much of this research was conducted in close collaboration with the Commercial, Stevedoring, Agricultural and Allied Workers Union (CSAAWU), which represents farm workers primarily on wine and fruit farms in the Western Cape. Working alongside this union allowed me to attend and observe union meetings, strikes and negotiations between the union and employers. I also interviewed staff at a variety of rural NGOs, commercial farm owners, farm workers, labour department officials, and staff from the commercial farmers' association Agri Wes-Cape. This research was conducted in the Western Cape province only and thus cannot be generalised to the entire country.

The strike wave highlighted low levels of unionisation among farm workers, and the difficulties unions face in building a base among these workers. It also revealed the restructuring of rural labour markets over the last thirty years, particularly the growth of a large pool of seasonal labour residing in rural townships and peri-urban areas. Seasonal labourers are, by virtue of the harvesting season, temporary workers. Some may be employed on the same farm the following year, but there is no guarantee of this. Permanent labour has been shed from commercial farms over a thirty-year period and farmers have changed the ways in which they recruit seasonal labour. In the past seasonal labour demands were met through the recruitment of women who lived on farms with their husbands (Ewert and Hamman, 1996; Ewert and Du Toit, 2005; FARE, 2013). The growth of rural townships and informal settlements in peri-urban areas has allowed farmers to recruit seasonal labour outside the farm. This shift has also allowed third-party recruiters (better known as labour brokers ${ }^{1}$ ) to manage the supply of labour in farming districts. The rural labour market is thus shaped by the vestiges of paternalist labour relations behind the farm gate and new forms of precarity, specifically labour broking. In this context, trade unions have struggled to organise farm workers. This was evident in the 2012-2013 strikes when workers rejected and openly expressed dissatisfaction with COSATU and formed independent committees that addressed wages, services and overall living conditions for farm workers (Hattingh, 2013; Wesso, 2013; Webb, 2016).

This paper begins with a discussion of the changing political economy of South African agriculture, focusing specifically on labour dynamics in the country's Western Cape province. The second part examines attempts by trade unions to organise farm workers and the twin challenges posed by paternalism and labour brokers. I conclude by arguing that the farm strikes highlight the need for a form of social movement unionism that goes beyond wage demands and tackles the multiple factors that influence poverty in rural areas. It is crucial that the direction for this comes from farm workers themselves rather than from the industrial trade unions located in urban centres.

\section{Farm Workers and the Political Economy of Agrarian Change}

Shortly after the 2012-2013 farm strikes, a report was released titled "The Future of Agriculture and

\footnotetext{
1 The term "labour broker" is used in South Africa to refer to a range of labour market intermediaries that, in other national contexts, are referred to as temporary employment agencies, staffing agencies or labour hire firms. While the statutory terminology in South Africa is "temporary employment services", the term labour broker is often used in public discourse, although it is seen by some firms to have a pejorative meaning. Labour brokers range from registered companies with thousands of employees to small operations supplying daily labour recruited from the side of highways and informal settlements.
}

Global Labour Journal, 2017, 8(1), Page 50 
the Rural Economy in the Western Cape", which included input by business, government, civil society and trade unions. The report had the following to say about the strikes:

What does seem clear, however, is that it was not only or primarily workers in full-time employment at the time that were involved, but workers who were seasonally employed on farms, or looking to find seasonal employment. It is also likely that many of those involved were and have remained unemployed. These were not therefore strikes in the traditional labour relations sense, as much as protest actions. They do not simply concern income and conditions of employment in the agricultural sector, but more broadly the rural economy and its social dimensions (FARE, 2013: 1).

The report foregrounds a key factor in the strikes: the growth of a large seasonal workforce employed temporarily on farms throughout the province. While farmers in the labour-intensive sectors like viticulture and horticulture have long employed seasonal workers, the FARE (2013: 28) report notes that, with some variation between farms, the proportion of seasonal to permanent workers has increased, and stands at about 80 per cent seasonal to 20 per cent permanent. The report also notes that evictions from commercial farms combined with migration from other areas of South Africa has led to the growth of townships in rural towns across the province. De Doorns, for example, a town at the centre of the 2012-2013 strikes, has a population of approximately 19000 (Stats SA, 2011). The N1 highway cuts through the centre of this town situated at the heart of the Hex River Valley, a region producing table grapes. On the west side of the highway lies the actual town of De Doorns, with a population that is 65 per cent coloured, and with an average annual household income of R29 400 per annum (US \$2 050 at time of writing). On the east side are the townships of Stofland, Mpumelelo and Lubisi, with a population that is 71 per cent black and an annual household income of R14 600 (US \$1 018) (Stats SA, 2011). The physical divide between racial groups in this community is an outcome of histories of labour migration, primarily from the Eastern Cape to the Western Cape. Many migrants who came to the valley seeking seasonal work have since settled permanently in rural townships like Stofland, Mpumelelo and Lubisi where they are reliant on seasonal work.

Why did this shift occur and what impact has it had on the livelihoods of rural workers? The answer requires us to turn to the ways in which the country's agricultural sector has been shaped by multiple and competing forces, particularly those that arose after the end of apartheid.

In the apartheid era, farm workers were excluded from legislation governing labour relations. After 1994 the ANC, with the support of its trade union partner COSATU, introduced a host of legislation aimed at protecting workers, and vulnerable workers in particular. These included: the Basic Conditions of Employment Act, which outlined conditions of work, hours, maternity leave and overtime pay; the Labour Relations Act, which extended the right to organise and strike to farm workers; the Extension of Security of Tenure Act, which provided farm workers with protections and legal resource in the case of evictions; and, in 2003, a Sectoral Wage Determination that provided a minimum wage level for all agricultural workers.

While these rights have been important victories for farm workers and trade unions, they have been implemented unevenly and have had mixed results (Naidoo, Klerck and Manganeng, 2007). Existing tenure security legislation, for example, has been widely criticised for failing to protect farm worker families, particularly women, from illegal evictions (Kleinbooi and Williams, 2010). A study by Wegerif, Russell and Grundling (2005) found that between 1984 and 2004 almost 1.7 million 
people were evicted from farms. Only 1 per cent of these evictions involved a legal court process. Their study also revealed the explicitly gendered nature of these evictions, with just over threequarters of those evicted being women and children (Wegerif et al., 2005: 41). Many of these evicted farm workers and their families ended up in rural townships or nearby cities, where they became a potential source of seasonal labour for surrounding farms.

State intervention during the apartheid era led to the high rates of agricultural growth, and by 1970 farm employment had peaked (Vink and Kirsten, 2000). By the 1980s the picture had changed significantly as the country entered a prolonged economic crisis and the mechanisation of agriculture decreased demand for labour (Marcus, 1989). Job losses were steep during this period, with 114000 regular jobs lost in agriculture between 1988 and 1996 (Kritzinger, Barrientos and Rossouw, 2004: 22). Since the 1980s there has been a marked decline in total agricultural employment across the country and farmers have significantly downsized their labour force in recent years (Du Toit and Ally, 2004; Kritzinger et al., 2004; Van der Burg, 2008; Greenberg et al., 2012). In 1988 agriculture employed some 1.22 million people nationally, which dropped to 914473 in 1996, and to 656000 in 2012 (Dept. of Agriculture, 2012). Seekings and Nattrass (2005) have suggested that labour market policies intended as pro-poor frequently had the opposite result. Labour and tenure protections, they argue, have resulted in massive evictions from commercial farms and high rates of unemployment among unskilled rural workers. While an increase in exports has raised demand for skilled workers, on some farms unskilled workers have been replaced through mechanisation or by recruiting seasonal labour off-farm - this is particularly the case in certain sectors of horticulture like table grape harvesting where mechanisation is not possible. Between 1995 and 2002 the share of semiskilled labour in agriculture rose by 64.7 per cent while the share of unskilled workers dropped by 44.1 per cent (Bhorat, 2004: 13).

Farmers also faced a rapidly changing economic landscape in the 1990s. Not only did the ANC government abolish many of the protections, regulations and subsidies that had safeguarded white commercial farmers, the end of apartheid also heralded the end of economic sanctions and the opening up of the economy to the international market. In the Western Cape's wine sector, the dismantling of regulatory systems and the insertion of the South African economy into global circuits of trade dramatically increased exports (Ewert and Du Toit, 2005). In the fruit industry, the stateestablished fruit export monopoly was dismantled and there followed a rapid growth of private export agents as farmers competed to sell their produce abroad (Kritzinger et al., 2004). In both the fruit and wine industries, power shifted from co-operatives to privately owned large enterprises that were able to capture the attention of global buyers, particularly major supermarket chains (Mather and Greenberg, 2003). As a result, one of the key trends in the agricultural sector has been consolidation, with larger farmers buying up medium and small producers in an attempt to compete in international markets. The introduction of neo-liberal economic reforms and labour and tenure legislation after 1994 has had the effect of accelerating changes that were already underway in the agricultural sector, namely the shift away from permanent employees living on farms, mechanisation and recruitment of seasonal labour off-farm.

Historically, commercial farmers in the Western Cape had employed a small number of permanent workers who resided on the farm with their families - in this lie the roots of paternalism discussed later. Typically, permanent workers would be male, with wives, daughters and mothers hired seasonally. One of the key shifts that the FARE (2013) report highlights is the shift in seasonal labour recruitment away from the farm and to rural towns and informal settlements. This shift 
toward recruiting seasonal labour off-farm was noted in a 2004 study by Du Toit and Ally where they found that 60 per cent of farms in six major agricultural districts in the Western Cape had reduced the size of their permanent labour force and were increasingly reliant on seasonal labour recruited through labour brokers. Other studies of labour restructuring in the deciduous and citrus fruit export sectors seem to corroborate these findings (Barrientos and Kritzinger, 2003; Mather and Greenberg, 2003; Kritzinger et al., 2004; Van der Burg, 2008). The restructuring of labour markets in rural areas is indicative of what Ewert and Du Toit (2005: 315) call a double divide, between farmers "who are able to profit from the opportunities offered by international expansion and those who are not, and secondly, between 'core' workers and those thrown out by casualization and externalization". The result has been the growth of a "rural lumpenproleteriat, often residing in rural, peri-urban or metropolitan shantytowns" (Ewert and Du Toit, 2005: 317). The shift to recruiting seasonal labour off farms has thus opened up space for labour brokers to act as intermediaries. While seasonal labour was always insecure, as workers are not necessarily guaranteed a job on the same farm (or anywhere) the following season, labour broking has exposed workers to additional levels of insecurity. In De Doorns, for example, competition between labour brokers for contracts on commercial farms has been blamed for the outbreak of xenophobic violence against foreign migrants in 2008, which saw thousands of migrant workers displaced from their homes (FARE, 2013).

\section{Workers and Unions: Between Precarity and Paternalism}

Fewer than six per cent of farm workers nationally belong to trade unions, and while there is no accurate data for farm workers in the Western Cape, estimates of union density range between 3 per cent and 11 per cent, which includes both permanent and seasonal workers (Human Rights Watch, 2011; Theron, 2011). A COSATU-commissioned report points out that unions are employing a model of organising entirely inappropriate for the agricultural sector, rooted in past access models derived from urban organising experiences (NALEDI, 2011). The report suggests that unions take into account the changing nature of rural social relations, and "recruit workers outside the farm using such methods as recruitment drives in town when farm workers go to buy groceries, meetings in social places such as shebeens and clubs, and providing members with both labour and social welfare services" (NALEDI, 2011: 76). As scholars of agricultural labour in South Africa have long noted, models of industrial unionism do not address the non-wage needs of rural workers (Du Toit, 1994).

Low levels of unionisation in the agricultural sector are due to three related factors. First, South African trade unions have largely been urban-based. This is an outcome of union involvement in the mass democratic movement that ended apartheid, which was concentrated in urban areas. Because unions tend to be urban-based, the type of organising model that they have pursued in agriculture has been at odds with the types of social relations that exist in rural areas. Labour relations on farms usually go beyond wage levels and encompass a broad range of concerns around housing, transport, education and services. As I discuss below, the persistence of paternalist labour relations on farms has made this type of organising very challenging. This "urban bias" is also reflected in the state's rural development strategy, which has prioritised the interests of a small class of black commercial farmers over farm workers and farm dwellers (Bernstein, 1996). State land reform policy has shifted from a focus on the rural poor and toward a market-friendly model of agrarian reform aimed at creating a black commercial farming class (Hall, 2004). Third, unions active in the agricultural sector have largely been unable to organise seasonal workers, and particularly those

Global Labour Journal, 2017, 8(1), Page 53 
employed by labour brokers. As a result, most have simply followed COSATU's line, calling for a total ban on labour brokers rather than attempting to organise these workers.

Labour broking is hardly new in South Africa. Historically, labour recruitment offices were set up in rural areas, particularly Bantustans, to supply workers to mines and factories (Wolpe, 1972; Moodie and Ndatshe, 1994; Theron, Godfrey and Lewis, 2005). Workers were made to sign contracts of limited duration in order to control political claims to reside in urban areas. However, these labour recruitment agents simply supplied labour; they were not the employer. As Theron et al.'s (2005) research on the history of labour broking in South Africa shows, the agencies that recruited migrant labour were the precursors to modern-day labour brokers. In the post-war period, South Africa witnessed the expansion of "temporary help" agencies of the kind that existed in other parts of the world - firms like Kelly and Manpower, for example. A 1983 amendment to the 1965 Labour Relations Act required labour brokers to register with the Department of Labour; it also deemed the broker to be the employer rather than the client. This occurred at a time when the migrant labour system was being dismantled and recruitment agencies were closing shop in the Bantustans. It is no surprise then that labour brokers stepped in to supply unskilled workers to sectors that had previously relied on recruiters.

The effect of the 1983 amendment was to legitimise the triangular employment relation between the broker, client and worker. Fast-forward to 1994, and post-apartheid labour legislation contains similar provisions legitimising this system further. In the absence of any legislation governing the amount of time workers can be classified as "temporary", brokers were free to extend work contracts for days, weeks or years as the client saw fit. In the context of economic liberalisation brought about by the state's 1996 Growth, Employment and Redistribution (GEAR) policy, firms restructured their operations using labour brokers to ensure flexibility and cut labour costs. The type of labour brokers operating in each sector varies significantly. As Theron et al. (2005) note, on one end of the spectrum are large and influential brokers like Adcorp who claimed to place 22000 workers. On the other end, and more common in the agricultural sector, is the "bakkie ${ }^{2}$ brigade", which involves someone with a truck, a cell phone and contacts in townships and rural areas. It is not uncommon to see these operators stopping on the N2 highway on the urban fringes of Cape Town, picking up workers by the truckload each morning.

The growth of labour broking has hardly been confined to the country's agricultural sector. While accurate data on the extent of labour broking is hard to come by, the National Association of Bargaining Councils suggests that total employment through labour brokers in 2012 was 979539 persons (COSATU, 2012). Researchers have estimated that approximately one-third of South Africans are now employed in contingent jobs, fixed-term contracts and informal occupations (Ceruti, 2010: 78). Some scholars have suggested that the state's embrace of neo-liberal policies in the late 1990s significantly undermined new labour legislation, creating a labour regime characterised by "regulated flexibility" which allowed for the proliferation of precarious forms of work (Clarke, 2004). For trade unions, the growth of labour broking threatens to undermine many of the gains workers have made since 1994. For this reason, one of COSATU's major campaigns in recent years has been to call on the state to ban labour broking outright.

However, the federation's campaign was unsuccessful and the government opted to regulate labour brokers through amendments to the 1995 Labour Relations Act (LRA). In 2014, Parliament

2 "Bakkie" is a South African colloquialism for a small pick-up truck. 
approved amendments to the LRA that would further regulate labour broking. The changes maintained the basic structure established by the 1983 amendments whereby the labour broker remains the employer; however, the amendments circumscribe the period for which a broker may place a worker with a client to three months. After this time the worker must be regarded as a permanent employee of the client and not of the labour broker, unless the position can be justified as being of a purely temporary nature (Department of Labour, 2014).

Trade unions active in the Western Cape's agricultural sector were divided over whether to support COSATU's call for a complete ban. The COSATU affiliate charged with organising farm workers, the Food and Allied Workers Union (FAWU), maintained that an outright ban would be the only way to reduce the worst exploitation in the labour market:

An outright ban would have been sufficient. It would have been the right thing to do. So it's certainly a defeat. I think the ANC was playing towards people who had money in terms of where their constituency is. We're very disappointed (Gafielden Benjamin, FAWU organiser, personal communication, 10 August 2012).

Regulating labour brokers was seen by FAWU as an act of class betrayal, as they saw the African National Congress (ANC) siding with business interests rather than with their partners in trade unions. This belief that the ANC was somehow "in bed" with labour brokers was widespread in 2012, and popularised by a story that linked president Jacob Zuma's son to a labour broker supplying workers to platinum mines (Merten, 2012).

Calls for a complete ban on labour brokers were also supported by smaller unions like CSAAWU, which organises primarily in the Breede River Valley near the town of Robertson. The union is fiercely independent and socialist in its orientation, eschewing any direct relationship with COSATU on the basis that COSATU is too pro-ANC and "favours a less confrontational role with the government and farmers" (Karel Swart, CSAAWU, personal communication, 9 June 2012). Nevertheless, CSAAWU supported COSATU-led marches against labour brokers and remains convinced that a ban is necessary to protect farm workers:

It is important to organise workers one way or the other, but we support COSATU's call for a ban. Even though we disagree sometimes with COSATU's position ... the ban is a political priority that is a political struggle for worker's dignity (Karel Swart, CSAAWU, personal communication, 9 June 2012).

For CSAAWU the ANC's decision to regulate rather than ban brokers was simply an affirmation that the ANC sides with business rather than workers.

Union officials were sceptical that amended labour legislation would assist seasonal farm workers who, due to the time-specific nature of their work, could be justified as temporary workers:

Hypothetically you're dealing with citrus, for example; it's cultivated and harvested at a certain time of year. There's no prospect here of permanent jobs for farm workers. They will remain a vulnerable group of workers, so there's no real protection, there's no permanency (Gafieldien Benjamin, FAWU organiser, personal communication, 10 August 2012).

The concern for most trade unions was that regulation of the labour broking sector would further entrench their role as legitimate agents supplying labour to the agricultural sector. This fear is not 
unfounded. As Clarke (2004) has demonstrated, labour legislation introduced after 1994 inadvertently contributed to the growth of precarious employment as employers sought legal loopholes. The regulations, as labour lawyer Paul Benjamin has argued, continue to allow for significant employment flexibility (IOL 2012). Seasonal work in the agricultural sector is already insecure as there is no guarantee that workers will be hired the following season. If workers are employed by a labour broker for three months during harvesting season, they are simply laid off and, if they are lucky, hired back the following year.

Sikhula Sonke, a women-led trade union active in the Western Cape, was not supportive of a ban. They argued instead in favour of regulations that provided workers with some type of stability from season to season:

We disagree with COSATU.... In the beginning of the year we were having a discussion around labour brokers and we raised issues that our members who work under labour brokers have been facing, and we also said that if there's a law that protects the workers who work for the broker then it will be very much better for us at Sikhuka Sonke because we know there's enough protection for them (Sikhula Sonke organisers, personal communication, 7 June 2012).

Union organisers claimed that disputes commonly occurred when workers were unsure of the identity of their employer. They would appeal to the farmer who would then direct them to the labour broker, deflecting responsibilities over pay and working conditions. Stories like this are all too common. For example, in 2002, 4000 workers employed at a gold mine east of Johannesburg went on strike because they demanded the broker pay them money received from the mine. Until the strike workers believed they were employed by the mine itself. As a result of the strike the employer terminated its contract with the broker, leaving 4000 workers unemployed (Benjamin, 2013).

All unions in this study were in favour of some form of state regulation, either an outright ban or regulation, yet few of them were committed to regulation from below through organising. In the words of one COSATU official, "Currently we don't have a strategy to organise those workers.... The world of work has restructured itself and as trade unions we're still structured in the same old way" (Mike Louw, COSATU Western Cape, personal communication, 27 June 2012). The historical legacy of South African trade unions as centralised organisations with a membership comprised largely of industrial workers in urban areas poses significant challenges. Instead of adapting to the changing world of work, COSATU and its affiliates have relied on more traditional forms of organising and representing workers (Barchiesi and Bramble, 2003). As one COSATU official admitted to me, the call to ban labour brokers was largely seen as a test of the political direction of the ANC rather than a realistic policy recommendation.

Unions surveyed in this research had largely confined their organising efforts to permanent farm workers residing on farms or workers in downstream agricultural processing. The reasons for this were twofold. First, it was easier to organise permanent workers because they worked in the same place over a long period of time and were relatively settled. Unions could negotiate not only for wage increases but also for upgrades to worker housing. Second, their wages tended to be higher and more stable than those of seasonal workers, which provided more financial stability for the union.

Low levels of unionisation among farm workers suggest that existing strategies are not effective and that organising in rural areas poses a unique set of challenges. The main one, identified by all trade union officials, was the persistence of paternalistic labour relations on farms. Or as one 
COSATU representative bluntly put it, "The difficulty historically in organising farm workers has been the master-slave relationship in those particular areas where farm workers have historically been based on the farms and they are reliant on the farmer for their livelihood" (Mike Louw, COSATU Western Cape, personal communication, 17 June 2012). Labour relations on farms are not easily separated from a broader set of social relations, as workers are dependent on farm owners for housing, electricity, education and crèche facilities, transport and entertainment and recreational infrastructure. As Du Toit (1993) notes, the farm is a different world of work, where obligations between the famer and worker extend beyond the labour-wage nexus. To live and work on the farm is to be seen as "a deel van een familie, or a part of one family" (Du Toit, 1993: 317).

Labour relations on Western Cape farms have been characterised by a racially hierarchical system of paternalism inherited from Cape slave society (Ewert and Du Toit, 2005). Within this system whiteness was equated not only with land ownership but also with structures of authority and deference. To be the baas ${ }^{3}$ of the farm is to have authority over one's wife and children but also over those who reside on the farm. At the heart of paternalism is a belief that worker and farmer share a common interest in the survival of the farm community (Du Toit, 1993; White, 2010). Paternalism underwent transformation in the 1980s when the Rural Foundation - an organisation established by agrarian capital and the apartheid state - initiated a programme of "upliftment" for workers and their families. As Ewert and Du Toit (2005) note, the Rural Foundation appealed to farmers to train workers, improve labour relations, and upgrade housing and worker amenities. This form of upliftment was thoroughly paternalist and was seen by the state and capital as a way of increasing productivity and reducing the risk of international sanctions. The entry of the state into farm labour relations following the end of apartheid eroded paternalism even further as workers began to organise and become aware of their rights under the new legislation. However, paternalism continues to exist in a variety of forms. It operates as a "palimpsest in which labour relationships are governed simultaneously by both formal codes of legislation and the personal relationships and implicit contracts of paternalist practice" (Ewert and Du Toit, 2005: 325). An example of this is described by Ewert and Hamman (1996) as "ethnic corporatism", in which coloured farm workers who reside permanently on farms have benefitted from equity-sharing, fair-trade and co-decision-making schemes, while black farm workers (many of whom migrate from the Eastern Cape or reside in periurban slums) do not enjoy any of these benefits and are seen only as seasonal workers.

Trade unions active in the Western Cape's agricultural sector all identified paternalism as the primary obstacle to organising farm workers, yet they offered divergent views on how best to confront it. All unions were committed to empowering farm workers through education and organising, and assisting them in claiming their rights as citizens rather than subjects of their employers. CSAAWU's Speak Out campaign, for example, calls for improvements in housing, transportation and childcare infrastructure, access to land for small-scale farmers, and wage equity between men and women. Sikhula Sonke focuses specifically on issues affecting women and children. In her study of the union, White (2010) notes that Sikhula Sonke is neither a union nor a social movement, but a hybrid of both which allows it to go beyond traditional trade union activities to tackle the livelihood concerns of its members. To this end the movement runs campaigns against sexual and gender-based violence, alcohol abuse in farming communities, and evictions. Both CSAAWU and Sikhula Sonke are hybrid organisations, focusing on wage and non-wage issues, albeit

3 Afrikaans for "boss", but also implying a form of workplace hierarchy along race and gender lines. 
primarily among permanent farm workers.

Where they differ is in their approach to labour relations. White (2010) notes that Sikhula Sonke makes an effort to build positive labour relations between the union and the employer. As the union's General Secretary at the time told her, "We try to build relationships. It disadvantages our members if you are constantly aggressive. On some farms, farmers and workers have a very good relationship and this empowers workers to do things for themselves" (White, 2010: 680-681). White also observes that Sikhula Sonke has never advocated striking as a way of resolving labour disputes, choosing instead to take cases to the Commission for Conciliation, Mediation and Arbitration (CCMA), a dispute resolution body set up under the 1995 Labour Relations Act. Referring disputes to the CCMA is an important strategy for addressing paternalism as "historically marginalized workers can engage the state as citizens rather than as subjects of their employers" (White 2010: 681). For Sikhula Sonke paternalism is both negotiated and contested; it is seen as potentially advantageous to workers with good employers and negative when employers refuse to engage with the union or other representative or state institutions. The erosion of paternalistic bonds, White (2010) warns, can have a potentially negative impact as workers lose access to the social benefits and provisions previously provided under paternalist labour relations.

For CSAAWU paternalism is seen as a structure that uses "intimidation and onkunde [ignorance] against workers" (CSAAWU, 2012). Paternalism creates an environment in which workers cannot express themselves and do not feel comfortable speaking out against labour and human rights abuses. For CSAAWU social relations on farms are underpinned by widespread violence against workers: "Sometimes the farmer thinks he has a god-given right to beat our people. So that is why we're trying to get the environment right, so we can start our mobilisation" (Karel Swart, CSAAWU, personal communication, 9 June 2012). This particular incident involved a farmer who allegedly ran over a worker with his car and then proceeded to beat the worker. Instead of arresting the farmer, the police put the worker in jail, where he sat for two days with three broken ribs. Stories like this one were not uncommon among union organisers, and it was evident that in rural areas systems of white supremacy allowed farmers to escape prosecution. The main challenge was thus getting the environment right on farms in order to allow workers to speak out about labour violations: "There's a hostile environment on the farms today. There is still a master-slave relationship. There can only be progress if there's a culture of human rights on the farms" (Karel Swart, CSAAWU, personal communication, 9 June 2012).

In November 2011, the union launched its Speak Out campaign in Robertson in the Western Cape. At the launch workers reported unsafe working conditions, lack of adequate housing, the threat of evictions and poverty wages (CSAAWU, 2012). The campaign spread to farms in the district, where workers held meetings reporting on the challenges they faced working and living on farms. The Speak Out campaign includes twenty demands, including ones for a living wage of R4 500 per month, wage equity between men and women, an end to labour broking and "piece work", and housing ownership rights for farm workers. The campaign has resulted in reprisals by farm owners, as shop stewards and union leaders have been fired or faced intimidation at work. As a result, the union has been embroiled in a number of lengthy CCMA battles, which quickly depleted its funds. These reprisals demonstrate the cost of challenging paternalist systems of authority and control. As the FARE (2013) report outlines, many farm owners remain recalcitrant or openly hostile in their dealings with unions.

Organisers from Sikhula Sonke took issue with CSAAWU's organising approach, noting that 
the union created unhelpful antagonisms between the union and farm owners, which ultimately did not assist farm workers:

CSAAWU, they are like in a hurry to refer a worker to the CCMA. Where we at Sikhula Sonke think that we first go to the farmer; we send him an email or letter and say: 'Look we want to settle this matter on the farm.' They don't have any time to do that long process; they will just look at the issue and then refer the matter to the CCMA.... That is the big difference between us and other big unions because we also look at it like this: At the end of the day we're trying to build a relationship between ourselves, the worker and the farm owner. Most of the farm owners like the way we are doing things and we are working with them because some of them are also asking: Why don't you tell the other trade unions to be like you? (Sikhula Sonke organisers, personal communication, 7 June 2012).

For CSAAWU, however, Sikhula Sonke's approach lacks a transformative politics that challenges power relations in farming districts:

Sikhula Sonke are not clear on what they want. They're not clearly political, but you're dealing with a political system. It's not just wages. A union exists because there is a political need. A union grows out of these conditions, and that's not how Sikhula Sonke sees the conditions. They're not tackling these issues politically with the bosses. We know that it's not individuals in the agricultural sector, it's the system as a whole. We are very clearly political, but Sikhula Sonke is not taking things politically (CSAAWU, personal communication, 9 June 2012).

Different approaches to labour relations can thus be seen as part of the fraught process of negotiating within and against paternalistic structures. While unions can bring cases of abuse or unfair dismissals to the CCMA, thereby challenging paternalism, some unions have opted to work within these structures in order to improve the livelihoods of their members. What is clear is that paternalism remains a struggle for all unions organising in this sector because the majority of their members are permanent workers. As White (2010) notes, many seasonal workers do not see themselves as farm workers and thus do not experience paternalism in the same manner. They do not reside on farms and many of them are only in farming districts as temporary migrants for part of the year. It was these workers, and the committees they established independently of trade unions, that were at the centre of the 2012-2013 strike.

\section{Conclusion: Some Reflections on the 2012-2013 Strikes}

The farm worker strikes demonstrated the weakness of unions in the agricultural sector and the impact of low wages and precarious employment among a growing pool of seasonal workers. In his analysis of the strikes, Wesso (2013) points out that for some time seasonal workers residing in informal settlements had been organising in committees. In De Doorns these committees were comprised predominantly of migrant workers from the Eastern Cape, although they included permanent workers and the unemployed. The decision to launch a strike and blockade highways across the province was taken by these committees, which put forward a demand for a R150 per day minimum wage, as well as paid maternity leave, an end to labour brokers, an end to piecework, rentfree housing, a moratorium on evictions and an end to police brutality. However, once the strike was

underway, commercial farmers refused to negotiate with worker committees, as they did not consider

Global Labour Journal, 2017, 8(1), Page 59 
them to be legitimate representatives of farm workers. This prompted COSATU to enter the strike and negotiate on behalf of farm workers.

The role of COSATU in this strike illustrates the deeply problematic way in which urban-based unions engage with rural workers. Consider this comment from the federations' Western Cape regional secretary: "When workers take action without direction and guidance, that is when the danger comes about.... they don't understand the parameters of the law and all the other stuff' (Hattingh, 2013: n.p.). For COSATU, farm workers were not organised and therefore lacked a political voice through which to communicate with employers and the state. While workers may have struggled to negotiate directly with farmers, it is untrue that they were unorganised. The entry of COSATU led to a shift of power away from strike committees, as negotiations were carried out in urban centres far away from workers and their committees. This distance between the union and workers is vividly illustrated by the federation calling from its Cape Town offices for the strikes to be suspended on numerous occasions. By ignoring worker committees, COSATU squandered an opportunity to build a democratic form of trade unionism that addressed the complex needs of rural dwellers (Hattingh 2013; Wesso, 2013). Unfortunately, COSATU's role in this strike is indicative of a far more widespread problem within the federation - the growing divide between union leadership and rank-and-file workers (Webster and Buhlungu, 2004).

The farm worker strikes were unprecedented in the agricultural sector, which is not known for its labour militancy. They are reflective of an unevenly developed agrarian landscape, defined by highly profitable commercial farmers, less successful small producers and growing pools of rural surplus labour. Land reform policies after the end of apartheid have maintained this structure of agrarian dualism that supports large-scale commercial farms and neglects smaller producers and farm workers (Hall, 2009; Cousins and Scoones, 2010). It is thus important to see these strikes not simply as labour actions, but as forms of social protest rooted in a deep crisis of rural livelihoods. Access to waged labour in agriculture remains the most important factor affecting the poverty status of rural households, yet vast numbers of workers in this sector earn low wages that do not shield them from poverty. While wage levels for permanent farm workers have improved since 2002 thanks to sectoral determination (Bhorat, Kanbur and Stanwix 2012), the median monthly earnings for agriculturalsector employees remains low at R1 213 (Stats SA, 2010). In the wake of the strike many farmers have applied to the Department of Labour for exemption to the minimum wage increases, claiming they cannot afford to pay them. As Naidoo et al.'s (2007) research on minimum wage implementation in the Eastern Cape demonstrates, farmers find ways of manoeuvring around wage increases.

The problem with much trade union organising in agriculture, as Du Toit (1993) points out, is that it often imputes a type of proletarian consciousness to farm workers. The result has been an inability and unwillingness to take the perceptions and class consciousness of farm workers as the basis of organising. Because of this, trade unions have made few inroads among workers in rural areas. While federations like COSATU claim to represent the most vulnerable workers, they have not made a serious attempt to organise workers who earn some of the lowest wages in the country and are frequently subject to violent forms of abuse in the workplace (Human Rights Watch, 2011). The decline of stable employment and the rise of seasonal and contract forms of work through labour brokers is not unique to the agricultural sector. Its expansion, and the general crisis of unemployment in South Africa, should force unions to grapple with the diverse and intersecting factors that render everyday life in rural as well as urban areas precarious. 


\section{REFERENCES}

Department of Agriculture (2012) Abstract of Agricultural Statistics. Available online at www.nda.agric.za/docs/statsinfo/Ab2012.pdf [accessed 30 August 2012].

Barchiesi, F. and T. Bramble. (2003). Rethinking the Labour Movement in the "New" South Africa. Burlington: Ashgate.

Barrientos, S. and A. Kritzinger (2003) Squaring the Circle: Global Production and the Informalization of Work in South African Fruit Exports. Journal of International Development, 16(1): 81-92.

Benjamin, P. (2013) Law and the Practice of Private Employment Agency Work in South Africa. ILO Sector Working paper No. 292. Available online at http://www.ilo.org/wcmsp5/groups/public/--ed_dialogue/---sector/documents/publication/wcms_231442.pdf [accessed 15 July 2016].

Bernstein, H. (1996). South Africa's Agrarian Question: Extreme and Exceptional? Journal of Peasant Studies, 23(2-3): 1-52.

Bhorat, H. (2004) Labour Market Challenges in Post-Apartheid South Africa. South African Journal of Economics, 72(5): 940-977.

Bhorat, H., R. Kanbur and B. Stanwix. (2012) Estimating the Impact of Minimum Wages on Employment, Wages and Non-wage Benefits: The Case of Agriculture in South Africa. Cape Town: Development Policy Research Unit, University of Cape Town.

Ceruti, C. (2010) One Class or Two? The Labour Reserve and "Surplus Population" in Marx and Contemporary Soweto. South African Review of Sociology, 41(2): 77-103.

Clarke, M. (2004) Ten Years of Labour Market Reform in South Africa: Real Gains for Workers? Canadian Journal of African Studies, 38(3): 558-574.

Commercial, Stevedoring, Agricultural and Allied Workers Union (CSAAWU) (2012) Speak Out Campaign Report. Cape Town: CSAAWU.

Congress of South African Trade Unions (COSATU) (2012) COSATU and NACTU Memorandum on Labour Broking. COSATU Today. Available online at http://www.cosatu.org.za/show.php?ID=5917 [accessed 24 June 2013].

Cousins, B. and I. Scoones (2010) Contested Paradigms of "Viability" in Redistributive Land Reform: Perspectives from Southern Africa. Journal of Peasant Studies, 37(1): 31-66.

Department of Labour (2014) Labour Relations Act and Amendments. Available online at http://www.labour.gov.za/DOL/legislation/acts/labour-relations/labour-relations-act [accessed 16 July 2016].

Du Toit, A. (1993) The Micro-politics of Paternalism: The Discourses of Management and Resistance on South African Fruit and Wine Farms. Journal of Southern African Studies, 19(2): 314-336.

Du Toit, A. (1994) Farm Workers and the "Agrarian Question". Review of African Political Economy, 21(61): 375388.

Du Toit, A. and F. Ally (2004) The Externalization and Casualization of Farm Labour in the Western Cape. Institute for Poverty, Land and Agrarian Studies. Available online at http://www.plaas.org.za/plaas-publication/rr16 [accessed 2 July 2012].

Ewert, J. and A. du Toit (2005) A Deepening Divide in the Countryside: Restructuring and Rural Livelihoods in the South African Wine Industry. Journal of Southern African Studies 31(2): 315-332.

Ewert, J. and J. Hamman (1996) Labour Organisation in Western Cape Agriculture: An Ethnic Corporatism? 
Journal of Peasant Studies, 23(2-3): 146-165.

Future of Agriculture and Rural Economy (FARE) (2013) The Future of Agriculture and the Rural Economy in the Western Cape. Fare Panel Report. Available online at http://www.hopcal.co.za/assets/dynamic/85/files/74/76/76_the-future-of-agriculture-and-the-ruraleconomy.pdf [accessed 16 July 2016].

Greenberg, S., P. Dyata, R. Hendricks, I. Jacobs and E. Lindoor (2012) Gendered Value Chain Analysis of Wine: From Farm Worker in South Africa to Consumer in Sweden. Afrikagrupperna. Available online at http://www.wfp.org.za/pdf/womenworkers_in_value_chain_coverpage_stephen_greenberg_200.pdf [accessed 15 February 2013].

Hall, R. (2004) A Political Economy of Land Reform in South Africa. Review of African Political Economy, 31(100), 213-227.

Hall, R. (2009) Land Reform for What? Land Use, Production and Livelihoods. In Another Countryside. Policy Options for Land and Agrarian Reform in South Africa, edited by R. Hall. Cape Town: Institute for Poverty, Land and Agrarian Studies, School of Government, University of the Western Cape.

Hattingh, S. (2013) Reaping What You Sow: Reflections on the Western Cape Farm Workers Strike. Monthly Review E-Zine. Available online at http://mrzine.monthlyreview.org/2013/hattingh210213.html [accessed 25 January 2014].

Human Rights Watch. (2011). Ripe With Abuse: Human Rights Conditions in South Africa's Fruit and Wine Industries. New York: Human Rights Watch. Available online at https://www.hrw.org/report/2011/08/23/ripeabuse/human-rights-conditions-south-africas-fruit-and-wine-industries [accessed 12 May 2012].

Independent Online (IOL) (2012) Labour Law Changes Keep Employers Flexible. IOL Online. Available online at http://www.iol.co.za/business/businessnews/labour-law-changes-keep-employers-flexible1.1360659\#.USZuEVpRjpg [accessed 12 January 2013].

Kleinbooi, K. and B. Williams (2010) Life Histories of Evicted Farm Workers: Five Case Histories Examined. Phuhlisani/PLAAS. Available online at http://www.phuhlisani.org.za/oid\%5Cdownloads\%5C20100621CWDMEvictionsCaseHistoriesSubmitte dK.pdf [accessed 13 August 2012].

Kritzinger, A., S. Barrientos and H. Rossouw (2004) Global Production and Flexible Employment in South African Horticulture: Experiences of Contract Workers in Fruit Exports. Sociologia Ruralis, 44(1): 17-39.

Marcus, T. (1989) Commercial Agriculture in South Africa: Modernising Super Exploitation. London: Zed Books.

Mather, C. and S. Greenberg (2003) Market Liberalisation in Post-Apartheid South Africa: The Restructuring of Citrus Exports after "Deregulation”. Journal of Southern African Studies, 29(2): 393-412.

Merten, M. (2012) Zuma Link to Labour Broking. Business Report. Available online at http://www.iol.co.za/business/business-news/zuma-link-to-labour-broking-1.1369721\#.UVr7-ltRjpg [accessed 26 August 2013].

Moodie, T.D. and V. Ndatshe (1994) Going for Gold: Men, Mines, and Migration. Berkeley: University of California Press.

Naidoo, L., G. Klerck and L. Manganeng (2007) The "Bite" of a Minimum Wage: Enforcement of and Compliance with the Sectoral Determination for Farm Workers. South African Journal of Labour Relations, 31(1): 25-46.

National Labour and Economic Development Institute (NALEDI) (2011) Identifying Obstacles to Union Organizing in Farms: Towards a Decent Work Strategy In the Farming Sector. Available online at http://www.ssonke.org.za/index.php?option=com_docman\&task=doc_download\&gid=19\&Itemid=2 [accessed 3 June 2012].

Seekings, J., and N. Nattrass (2005) Class, Race and Inequality in South Africa. New Haven: Yale University Press.

Global Labour Journal, 2017, 8(1), Page 62 
Sinwell, L. and S. Mbatha (2016) The Spirit of Marikana: The Rise of Insurgent Trade Unionism in South Africa. London: Pluto Press.

Statistics South Africa (Stats SA) (2010) Monthly Earnings of South Africans. Available online at http://www.statssa.gov.za/publications/P02112/P021122010.pdf [accessed 3 June 2012].

Statistics South Africa (Stats SA) (2011) Census 2011. Available online at http:/ /www.statssa.gov.za/?page id=3839 [accessed 18 July 2016].

Theron, J. (2011) Sour Grapes. Law, Democracy \& Development, 14(1): n.p. University of Cape Town: Institute of Development and Labour Law.

Theron, J. (2012) Prisoners of a Paradigm: Labour Broking, the "New Services" and Non-standard Employment. Acta Juridica, 12: 58-83.

Theron, J., S. Godfrey and P. Lewis (2005) The Rise of Labour Broking and Its Policy Implications. Cape Town: Institute of Development and Labour Law, University of Cape Town. Available online at http://www.idll.uct.ac.za/idll/resources/monograph [accessed 4 June 2012].

Van der Burg, A. (2008) Going for Broke: A Case Study of Labour Brokerage on Fruit Farms in Grabouw. Stellenbosch: The Women on Farms Project and The Centre for Rural Legal Studies. Available online at http://www.worldcat.org/title/going-for-broke-a-case-study-of-labour-brokerage-on-fruit-farms-ingrabouw/oclc/546328288 [accessed 16 July 2012].

Vink, N. and J. Kirsten (2000) Deregulation of Agricultural Marketing in South Africa: Lessons Learned. No. 25. Johannesburg: The Free Market Foundation.

Webb, C. (2016) Fire in the Vineyards: Farm Workers and Agrarian Change in Post-Apartheid South Africa. In Domains of Freedom: Justice, Citizenship and Social Change in South Africa, edited by Melissa Levin, Thembela Kepe and Bettina von Lieres. Cape Town: UCT Press.

Webster, E. and S. Buhlungu (2004) Between Marginalisation and Revitalisation? The State of Trade Unionism in South Africa. Review of African Political Economy, 31(100): 229-245.

Wegerif, M., B. Russell and I. Grundling (2005) Still Searching for Security: The Reality of Farm Dweller Evictions in South Africa. Polokwane North: Nkuzi Development Association. Available online at http://lamosa.org.za/resources/EVICTIONS\%20BOOK.pdf [accessed 22 March 2012].

Wesso, R. (2013) Worker Organizing during the Farm Worker Strike. Surplus People's Project. Available online at http://www.spp.org.za/worker-organising-during-the-farm-worker-strike/ [accessed 23 January 2014].

White, F. (2010) Deepening Democracy: A Farm Workers' Movement in the Western Cape. Journal of Southern African Studies, 36(3): 673-691.

Wolpe, H. (1972) Capitalism and Cheap Labour-power in South Africa: From Segregation to Apartheid. Economy and Society, 1(4), 425-456.

\section{ACKNOWLEDGMENTS}

I would like to thank Pablo Idahosa, Richard Saunders, Viviana Patroni, Blair Rutherford, Fahim Quadir and Sharada Srinivasan for their feedback on this paper. I acknowledge the support of the Canadian Social Sciences and Humanities Research Council. 


\section{BIOGRAPHICAL NOTE}

CHRISTOPHER WeBB is a PhD Candidate in the Department of Geography and Planning at the University of Toronto and a Research Associate with the International Labour Research and Information Group (ILRIG) in Cape Town. [Email: chris.webb@mail.utoronto.ca] 